\title{
BANKERS' PERCEPTION ON THE DETERMINANTS OF CREDIT RISK IN CASE OF ETHIOPIAN COMMERCIAL BANKS
}

\author{
Mohammed Sultan Jabir', Million Gizaw Tole ${ }^{2}$ \& Haymanot Alemayehu Wolde ${ }^{3}$ \\ 1,2,3 Department of Accounting and Finance, Jimma University, Ethiopia \\ mamalu047@gmail.com, milli.gezaw@yahoo.com, haymalem@gmail.com
}

\section{Original Scientific Paper 10.5937/jouproman8-26878}

\begin{abstract}
The concern of this study is investigating the perception of bankers on the determinants of credit risk in Ethiopian commercial banks. Descriptive research design has been adopted in the study. In order to come across with the bankers perception, the study extensively used questionnaire. Bankers have been selected from 8 commercial banks operating in Ethiopia by using purposive sampling technique. The questionnaire was prepared to be filled by loan officers, relationship managers, credit analysts, credit directors and credit related position holders who work at each banks head office. The respondents were asked to give their perception about credit risk determinants by considering banks specific determinants, industry specific determinants and macro-economic determinants. Accordingly, based on the data generated the study found that from banks specific determinants poorly negotiated credit terms, compromised integrity in lending, poor credit risk assessment and higher rate of interest are the major causes for non-performing loans. Besides, from bank specific factors the study identified that the level of information sharing among banks has a direct effect on non-performing loans. The study also revealed that from macroeconomic factors a rise in inflation rate, unemployment and foreign exchange rate decreases loan quality. The researchers suggests that to minimize credit risk the bank's research and development department or the corporate planning division should perform a precise quantitative and qualitative analysis on Non-performing loan determinants so as to act in a proactive and defensive ways.
\end{abstract}

Key words: Non-performing loans, Bankers perception, Bank specific determinants, Industry specific determinants, Macro-economic determinants

\section{Introduction}

\subsection{Background of The Study}

Any country's economic system highly relies on the institutions that mobilize financial resources from those with surplus of funds to those with a deficit. Among these institutions the most significant one is a bank. Banks have significant role in the economy of any country. Availing credit to those who need is one means by which banks contribute to the growth of economy. Banks usually serve as a bridge between funds providers and borrowers so that the smooth flow of funds can take place in the economy. While playing such role in the economy, the banking system is usually exposed for various risks. Among these risks; credit risk, interest rate risk, operational risk, liquidity risk and foreign exchange risk are the most common in the banking industry.

Though aforementioned risks are thought as the most common banking risks, credit risk is the significant of all of them in the central activity of banks. 
Credit risk is a risk that occurs if borrowers fail to pay their debt fully or partially within a given time period. Credit risk is inherent risk in the very nature of banking activity. There are various factors that affect credit risk. These factors can be internal which are bank specific factors or they can be external which are beyond the boundary of banks. Some of the internal factors include the credit assessment of the bank, credit monitoring and follow-up, the asset size, the ownership type, and the like. On the other hand, the external factors include the Growth Domestic Product (GDP), inflation rate, unemployment rate, foreign exchange rate, and the like. Knowing the significance of credit risk in the banking industry, various studies have been undertaken in different developed and developing countries by giving an emphasis on the determinants of credit risk. Some of such studies are presented as follows.

In the study made by Das and Ghosh (2007)entitled "Determinants of Credit Risk in Indian State owned Banks" have found that of the macro level determinants, GDP as the most significant determinant of credit risk while real loan growth and bank size as a significant credit risk determinants at the bank level. On the other hand, the study performed by Samad (2012) regarding the credit risk determinants in US banks reveals that loan-loss allowance to non-current loans, credit loss provision, and non-current loans to loans are the significant predictors of credit risk and hence for bank failure.

In addition to the studies presented above, there are also many studies which are conducted under the same or related titles in different countries. Similar studies are also conducted on Ethiopian banks. However, to the researchers best knowledge, there is no a study performed in Ethiopia by giving emphasis on determinants of credit risk based on the perception of bankers. Hence, this study is undertaken by mainly involving the perception of bankers on credit risk determinants in Ethiopian Commercial Banks. By doing so, the existing literature gap on the subject matter can be enhanced and also some possible policy implications can be drawn.

\subsection{Statement of the problem}

In order to maximize the shareholders wealth, which is the principal objective of any firm, it is straightforward to give emphasis for the risks that cause major effect on the survival of the firm. Banks being crucial parts of the economic system of any country, their performance usually matters not only for the shareholders but also for the health of the economy of a country as well. Hence, credit risk being the substantial risk of all others, determining the factors that affect credit risk is very necessary and important. That is why the issue of credit risk of banks gained an increasing attention by many of recent studies.

If we look at experiences in developed and developing countries we can observe that credit risk has been the main risk in a bank. Indeed, (Fofack, 2005) witnessed that the major factor behind the fall of many banks around the world has been the failure to collect loans granted to customers.

According to the survey report of NBE (2009) credit risk is the main challenge in Ethiopian banking sector. 
This survey indicates that even if commercial banks in Ethiopia are suffering ongoing efforts to control bank-lending activities, there is weak practice of risk management in banks and this indicates supervisory concerns. Thus, (NPLs are still a major concern and a reflecting problem in the Ethiopian banking sectors.

The severity of credit risk on the health of a bank will be far reaching unless it is properly managed. The management over credit risk would better be undertaken if the determinant factors of this risk are understood and strict follow-up over such factors is made by banks. This study intends to investigate the determinant factors of credit risk in Ethiopian commercial banks from the view point of the perception of bankers.

\subsection{Research questions}

The following principal questions have been raised in order to address the problems and achieve objectives of the study;

1. What is the effect of bank specific determinants on NPLs in Ethiopian commercial banks?

2. To what extend the industry in which a bank operates affect the quality of loans?

3. What is the effect of macroeconomic variables on NPLs?

\subsection{OBJECTIVES OF THE STUDY}

\section{General objective}

The main objective of this study is to explore the perception of bankers on the determinants of credit risk in Ethiopian Commercial banks.

\section{Specific objectives}

In addition to aforementioned general objective, the study also has the following specific objectives

To identify the significant banks specific determinants of credit risk in Ethiopian commercial banks

To investigate the significant macro level determinants of credit risk

$>$ To investigate the significant industry level determinants of credit risk

\section{LITERATURE REVIEW}

The principal profit making activity of commercial banks is providing loans to its customers. While doing this banks will be exposed for credit risk. Credit risk as defined by Basel committee on banking supervision (2000), is the likely that a bank borrower or counterparty will unable to meet its obligations as per the agreed up on time, and for most banks, loans are the largest sources of credit risk. The effective management of credit risk is a critical component of a comprehensive approach to risk management and essential to the long-term success of any bank.

Management of credit risk is a strategy towards managing uncertainties through risk assessment, developing strategies to manage it, and mitigation of risk using managerial resources. Credit risk/nonperforming loans (NPL) will be associated with bank specific determinants, industry specific determinants or macro-economic determinants. 
Bank specific determinants of NPL's may emanate from credit terms of the bank, credit size, credit assessment, diversification and portfolio of loan, credit monitoring and follow-up, cost of loan, bank size and ownership type. Different studies have been performed by many researchers by considering such factors. For instance, in the study performed by Jimenez and Saurina (2005) on the Spanish banking sector, and Rajan and Sarat (2003) on Indian commercial banks, NPLs are found to be determined by lenient credit terms.According to Boudriga A., et al., (2009) and Dash and Kabra, (2010) a rise in credit volume is associated with a fall on non-performing loans. This is because the true credit quality of borrowers is effectively evaluated more likely when banks focus on their credit activity.

Waweru and Kalani (2009) in their study on commercial banks in Kenya revealedthat one of the internal factors that leads to occurrence of NPLsis high interest rate charged by banks. Thiagarajan S., et al., (2011) and Boudriga A., et al., (2009) argue that there is a negative association between banks asset size and NPLs. The study performed by $\mathrm{Hu}$ et al (2006) regarding the relationship between NPLs and commercial banks ownership structure found that banks with higher government ownership recorded lower NPLs.

Additionally, Nonperforming loans of banks can also be affected by business and institutional environment under which firms and individuals operate. Level of information sharing among banks and foreclosure laws are some of institutional environment factors which will affect
NPLs. Effective measures should be taken by countries to strengthen legal framework, improve the functioning of governmental bodies and reduce corruption to contribute to reducing banks credit risk and to insure the stability of the financial system.

Macroeconomic environment also influences the quality of a loan portfolio in the banking sector which could arise as a result of Gross Domestic Product (GDP), real effective exchange rate, annual inflation rate, as well as annual unemployment rate, among others. Dash and Kabra, (2010); Fofack, (2005); Vogiazas and Nikolaidou (2011), suggests that macroeconomic factors, specifically the real GDP growth have a significant negative relationship with NPLs. Dash and Kabra, (2010) in analyzing NPLs sensitivity to macroeconomic and bank specific factors in India ensured that real effective exchange rate which is macrofactor affects significantly NPLs. Moreover, Babouček and Jančar (2005) examined Czech banking sector by focusing on the effects of macroeconomic factors on the loan quality and they found positive correlation of non-performing loans with inflation and unemployment rate.

\section{Research design \& methodology}

This study has applied descriptive research design. To investigate the banker's perception on determinants of credit risk in Ethiopian commercial banks and to achieve the objective of the study, primary source of data has been extensively used. In order to collect data from the primary source, questionnaire was used. 
The questionnaire was prepared by having close ended questions mainly in the form of five point Likert scale to be filled by loan officers, relationship managers, credit analysts, credit directors and credit related position holders which work at each banks head office.

In Ethiopia the number of commercial banks which are operational until this research period are 19. From this, the research focused on commercial banks of Ethiopia those who provide banking service between the periods of 2004 and 2014 using purposive sampling technique. The researchers wants to make such a cutoff period by believing their experience in the industry will matter in order to acquire reliable and solid data about the factor under consideration. The number of banks operating between these periods are 8. By applying purposive sampling technique, 81 respondents (bankers') from the selected banks working in different positions have been participated in the study. Finally, the data collected from respondents is analyzed and interpreted using descriptive analysis of statistical tools like table, figures and percentages.

\section{DATA PRESENTATION AND INTERPRETATION \\ 4.1 General Characteristics of Respondents}

The data for this study has been gathered from 81 respondents (bankers) operating in different positions of banks at head offices. Out of these respondents 64 of them are first degree holders while the remaining 17 of them are Masters degree holders. 21 respondents have 1 to 5 years of experience in the banking industry, 34 respondents 6 to 10 years experience, 18 respondents 11 to 15 years experience and the remaining 8 respondents have more 16 years of experience in the banking industry. So, the researchers believe that based on the profile of the respondents the data generated from them is highly concrete.

\subsection{Types of banks loan contributing for Non- performing Loans (NPLs)}

Respondents of this research were asked to indicate the types of loans their bank is providing and its contribution for NPLs. Accordingly their response has been presented in the following table.

Table 1: The banks lending activity which is highly contributing for NPL

\begin{tabular}{|l|l|l|l|}
\hline Statement & Options & Frequency & Percent \\
\hline Which sector of the bank's & Agriculture & 31 & 38.3 \\
lending is contributing more & Domestic trade and services & 19 & 23.5 \\
for NPL? & Personal & 9 & 11.1 \\
& Construction & 8 & 9.9 \\
& Manufacturing & 7 & 8.6 \\
& Export and import & 5 & 6.2 \\
& Other & 2 & 2.5 \\
\hline
\end{tabular}

Source: Survey result and own computation 
As shown in table 1, the major nonperforming loans of the sampled banks is coming from the loans provided for purposes of agriculture and domestic trade and services, while the least portion of non-performing loans is covered by export and import loans. Put differently respondents were asked to mention the measures banks should take to minimize credit default. Accordingly in their response they have listed measures like; strengthening physical follow-up, strengthening initial screening of borrowers, requesting appropriate collateral and collateral substitutes, giving discount (other incentive) to promote payment, penalties (sanctions) for late payments and providing technical support after loan extension to be considered by banks so that credit default can be reduced.

\subsection{Descriptive Statistics}

The analysis and interpretation of the results obtained from respondents about the determinants of credit risk is addressed in the following section. The analysis is made by classifying the determinants into three separate sections as bank specific determinants, industry specific determinants and macroeconomic determinants as follows.

\subsubsection{Bank specific determinants of NPL}

To maintain long run success, banks should identify causes of credit risk and then apply appropriate management over such risk. Unlike macroeconomic variables which are common to all banks which operate in the same economy/environment, bank specific related variables which affect NPL are not necessarily similar from one bank to another bank. This means one variable may affect NPL of one bank but not the other. There are many types of bank specific determinants. The next section is concerned with analyzing and interpreting different bank specific determinants of credit risk as per the perception of bankers.

\section{Credit terms}

Banks usually establish or use credit terms in order to use them while providing loans to their customers. These credit terms have their own effect on the quality of loans or on the performance of loans. Thus, while well-established credit terms minimize the probability of loan defaults, the poor credit terms will expose the bank for high amount of defaults. Accordingly, respondents were asked to show their level of agreement for statements raised with respect to the relationship of credit terms with occurrence of non-performing loans and their response is summarized in the table 2 below. As we can see from the table large number of respondents agreed that lenient/lax credit terms (mean 2.37 and standard deviation 1.111) and poorly negotiated credit terms (mean 2.284 and standard deviation 1.027) are the major causes for non-performing loans. This finding of the study is consistent with the findings brought in the study made by Jimenez and Saurina (2005). 
Table 2: statements relating to credit terms and occurrence of NPL

\begin{tabular}{|l|l|l|l|l|l|l|l|l|}
\hline S.no & \multicolumn{1}{|c|}{ Statement } & $\begin{array}{c}\text { SA (1) } \\
\%\end{array}$ & $\begin{array}{l}\text { A (2) } \\
\%\end{array}$ & $\begin{array}{l}\text { N (3) } \\
\%\end{array}$ & $\begin{array}{l}\text { DA (4) } \\
\%\end{array}$ & $\begin{array}{l}\text { SDA (5) } \\
\%\end{array}$ & Mean & $\begin{array}{l}\text { Standard } \\
\text { Deviation }\end{array}$ \\
\hline 1 & $\begin{array}{l}\text { Credit terms which are lax will } \\
\text { cause loan default }\end{array}$ & 22.2 & 42 & 16 & 16 & 3.7 & 2.37 & 1.111 \\
\hline 2 & $\begin{array}{l}\text { If credit terms not well understood } \\
\text { by borrowers, they may default }\end{array}$ & 7.4 & 34.6 & 14.8 & 37 & 6.2 & 3.00 & 1.129 \\
\hline 3 & $\begin{array}{l}\text { If credit terms are poorly } \\
\text { negotiated, it leads to loan non } \\
\text { performance }\end{array}$ & 18.5 & 54.3 & 11.1 & 12.3 & 3.7 & 2.284 & 1.027 \\
\hline
\end{tabular}

Source: Survey Outcome and own computation

Note: SA - Strongly Agree $\quad$ A - Agree $\quad$ N- Neutral $\quad$ DA - Dis Agree $\quad$ SDA - Strongly DisAgree

\section{Credit size}

Banks provide loans in different amounts for different groups of customers. The staffs of the banks were asked different questions regarding the level of relationship between the volume of credit and credit risk. Accordingly, as presented in the following table 3, aggressive lending, banks great risk appetite and compromised integrity have achieved a higher positive agreement among large number of respondents by being main causes for NPL's. These items have a standard deviation value of 2.407, 2.88 and 2.33 respectively. On the other hand the finding from respondents revealed that the contribution of banks continuous credit growth towards NPL is fairly less compared to other related factors. This specific finding of the study is similar with the findings made by Boudriga A., et al., (2009) and Dash and Kabra, (2010), while the findings of Fernandez de Lis, et al. (2000) and Thiagarajan S., et al. (2011) describe the reverse.

Table 3: Statements relating to credit size and occurrence of NPL

\begin{tabular}{|l|l|l|l|l|l|l|l|l|}
\hline S.no & \multicolumn{1}{|c|}{ Statement } & $\begin{array}{c}\text { SA } \\
\%\end{array}$ & $\begin{array}{l}\text { A } \\
\%\end{array}$ & $\begin{array}{l}\text { N } \\
\%\end{array}$ & $\begin{array}{l}\text { DA } \\
\%\end{array}$ & $\begin{array}{l}\text { SDA } \\
\%\end{array}$ & $\begin{array}{l}\text { Mean } \\
\text { Deviation }\end{array}$ \\
\hline 1 & $\begin{array}{l}\text { NPL volume or ratio will become high } \\
\text { if there is aggressive lending }\end{array}$ & 22.2 & 40.7 & 16 & 16 & 4.9 & 2.407 & 1.148 \\
\hline 2 & $\begin{array}{l}\text { For banks whose credit growth is } \\
\text { rapid, there is huge NPL }\end{array}$ & 9.9 & 16 & 38.3 & 25.9 & 9.9 & 3.098 & 1.102 \\
\hline 3 & $\begin{array}{l}\text { If a bank has a great risk appetite, it } \\
\text { will cause NPLs }\end{array}$ & 16 & 35.8 & 19.8 & 21 & 6.2 & 2.888 & 2.444 \\
\hline 4 & $\begin{array}{l}\text { When there is compromised integrity } \\
\text { in lending, it leads to loan default }\end{array}$ & 19.8 & 49.4 & 13.6 & 12.3 & 4.9 & 2.333 & 1.083 \\
\hline
\end{tabular}

Source: Survey Outcome and own computation 


\section{Diversification and period of loan}

Theoretically, diversification reduces risk taking as it makes possible the compensation for losses in some product by gains in others. It is obvious that the level of credit risk differs between types of loans and classes of borrowers. Banks' percentage of NPL can be influenced by the composition of its loan portfolio. Having opportunity to lend money to diversified range of borrowers banks can successfully reduce their impaired loans (minimizing risk of individual borrower).As the response presented in the following table 4 shows making a diversified loan into different sectors of the economy has been believed by respondents in reducing the default level to a higher extent. This has been ensured by majority $(75.3 \%)$ of respondents along with having a mean value and standard deviation of 2.172 and 0.877 respectively.

Table 4: Statements relating to diversification and period of loan and occurrence of NPL

\begin{tabular}{|l|l|c|c|c|c|c|c|c|}
\hline S.no & \multicolumn{1}{|c|}{ Statement SA } & A & N & DA & SDA & Mean & $\begin{array}{l}\text { Standard } \\
\text { Deviation }\end{array}$ \\
\hline 1 & $\begin{array}{l}\text { Diversification of a loan into } \\
\text { different sectors decreases the ratio } \\
\text { of default }\end{array}$ & 18.5 & 56.8 & 14.8 & 8.6 & 1.2 & 2.172 & 0.877 \\
\hline 2 & $\begin{array}{l}\text { Loans provided on a long term } \\
\text { basis tends to turn to NPL than } \\
\text { short and middle term loans. }\end{array}$ & 11.1 & 35.8 & 19.8 & 28.4 & 4.9 & 2.802 & 1.122 \\
\hline
\end{tabular}

Source: Survey Outcome and own computation

\section{Credit assessment}

Making proper credit assessment on the borrower regarding the borrower's capacity, capital, collateral and other related aspects is vital to enhance the quality of the loan. The staffs of the banks were asked different questions regarding the relationship between credit assessment and credit risk and their response is shown in table 5. According to the response generated from the staffs significant agreement of the staffs over the statements is observed on almost all statements posed in the table. This shows that a good credit quality, Know your customer policy of banks and good loan underwriting leads to a high loans quality. On the other hand, poor credit risk assessment and lack of skilled manpower in credit assessment and analysis would lead to loan default. 
Table 5: Statements relating to credit assessment and occurrence of NPL

\begin{tabular}{|l|l|l|l|l|l|l|l|l|}
\hline S.no & \multicolumn{1}{|c|}{ Statement } & $\begin{array}{l}\text { SA } \\
\%\end{array}$ & $\begin{array}{l}\text { A } \\
\%\end{array}$ & \multicolumn{1}{|c|}{$\begin{array}{l}\text { DA } \\
\%\end{array}$} & $\begin{array}{l}\text { SDA } \\
\%\end{array}$ & Mean & $\begin{array}{l}\text { Standard } \\
\text { Deviation }\end{array}$ \\
\hline 1 & $\begin{array}{l}\text { A good credit quality of a borrower } \\
\text { approves a loan quality }\end{array}$ & 35.8 & 51.9 & 11.1 & 1.2 & 0 & 1.777 & 0.689 \\
\hline 2 & $\begin{array}{l}\text { Easily admitted borrowers usually } \\
\text { default }\end{array}$ & 11.1 & 28.4 & 45.7 & 11.1 & 3.7 & 2.679 & 0.946 \\
\hline 3 & $\begin{array}{l}\text { Policy of banks about Know your } \\
\text { customer leads to high quality of loans }\end{array}$ & 44.4 & 46.9 & 7.4 & 1.2 & 0 & 1.654 & 0.673 \\
\hline 4 & $\begin{array}{l}\text { Good loan underwriting ensures loan } \\
\text { performance }\end{array}$ & 19.8 & 61.7 & 9.9 & 8.6 & 0 & 2.074 & 0.802 \\
\hline 5 & $\begin{array}{l}\text { Poor credit risk assessment would lead } \\
\text { to loan default }\end{array}$ & 39.5 & 54.3 & 3.7 & 1.2 & 1.2 & 1.703 & 0.714 \\
\hline 6 & $\begin{array}{l}\text { Lack of skilled man power in credit } \\
\text { assessment and analysis affects loan } \\
\text { quality }\end{array}$ & & & & & 0 & 1.642 & 0.638 \\
\hline
\end{tabular}

Source: Survey Outcome and own computation

\section{Credit monitoring and follow-up}

The provision of loan has to be succeeded by monitoring and follow-up over the borrowers' loan usage by concerned bodies of the bank in order to ensure effective utilization of loan as well as to minimize the occurrence of loan default. The finding from respondents as shown in the following table 6indicates that large number of respondents $(91.3 \%)$ (mean 1.777 and standard deviation 0.67 ) believe strict credit monitoring can ensure loan performance. In addition to this large number of respondents believe that NPLs can be reduced if banks (i) properly monitor poorly assessed and advanced loans (ii) follow-up their loans and (iii) allocate higher budgets for loan monitoring.

Table 6: Statements relating to credit monitoring/follow-up and occurrence of NPL

\begin{tabular}{|l|l|l|l|l|l|l|l|l|}
\hline S.no & \multicolumn{1}{|c|}{ Statement } & $\begin{array}{l}\text { SA } \\
\%\end{array}$ & $\begin{array}{l}\text { A } \\
\%\end{array}$ & $\begin{array}{l}\text { N } \\
\%\end{array}$ & $\begin{array}{l}\text { DA } \\
\%\end{array}$ & $\begin{array}{l}\text { SDA } \\
\%\end{array}$ & Mean & $\begin{array}{l}\text { Standard } \\
\text { Deviation }\end{array}$ \\
\hline 1 & $\begin{array}{l}\text { Strict credit monitoring ensures } \\
\text { loan performance }\end{array}$ & 33.3 & 58 & 6.2 & 2.5 & 0 & 1.777 & 0.67 \\
\hline 2 & $\begin{array}{l}\text { Poorly assessed and advanced } \\
\text { loans, if properly monitored, may } \\
\text { perform well. }\end{array}$ & 7.4 & 40.7 & 24.7 & 21 & 6.2 & 2.777 & 1.06 \\
\hline 3 & $\begin{array}{l}\text { There is direct linkage between } \\
\text { loan follow-up and occurrence of }\end{array}$ & 13.6 & 42 & 9.9 & 25.9 & 8.6 & 2.74 & 1.232 \\
\hline 4 & $\begin{array}{l}\text { Banks with higher budget for loan } \\
\text { monitoring have lower NPLs }\end{array}$ & 9.9 & 37 & 43.2 & 9.9 & 0 & 2.53 & 0.807 \\
\hline
\end{tabular}

Source: Survey Outcome and own computation 


\section{Cost of loan}

As it is known the principal source of income for banks is interest income. In the mean while the rate of the interest that banks charge over their lending's will have an impact on NPLs. In this regard bankers those who took part in this study were asked to give their agreement level for the statements raised regarding the relationship between cost of loans (interest rate) and the occurrence of NPLs.
Accordingly, their response as it is presented in the following table 7 shows majority of the respondents $(59.3 \%)$ (mean 2.617 and standard deviation 1.078) agreed that the performance of loans will be affected as a result of interest rate. The response generated indicates that banks which charge higher interest rate over their lending's will face higher NPL ratios while banks with lower lending rates will have a lower ration of NPLs.

Table 7: Statements relating to cost of loan (interest) and occurrence of NPL

\begin{tabular}{|l|l|l|l|l|l|l|l|l|}
\hline S.no & \multicolumn{1}{|c|}{ Statement } & $\begin{array}{c}\text { SA } \\
\%\end{array}$ & $\begin{array}{c}\text { A } \\
\%\end{array}$ & $\begin{array}{l}\text { N } \\
\%\end{array}$ & $\begin{array}{l}\text { DA } \\
\%\end{array}$ & $\begin{array}{l}\text { SDA } \\
\%\end{array}$ & Mean & $\begin{array}{l}\text { Standard } \\
\text { Deviation }\end{array}$ \\
\hline 1 & $\begin{array}{l}\text { Loan price (interest rate) affects } \\
\text { loan performance }\end{array}$ & 9.9 & 49.4 & 14.8 & 21 & 4.9 & 2.617 & 1.078 \\
\hline 2 & $\begin{array}{l}\text { Charging high interest rate leads to } \\
\text { loan default }\end{array}$ & 8.6 & 35.8 & 23.5 & 27.2 & 4.9 & 2.839 & 1.077 \\
\hline
\end{tabular}

Source: Survey Outcome and own computation

\section{Banks size}

Banks accumulate assets over their operating periods in different forms. These assets make some banks giant and others miniature. In fact large banks with more assets will have more resources for developing protocols and training of credit officers and more experimented to deal better with bad borrowers and more effective in screening loan customers than banks with fewer assets. The size of banks asset in some cases observed to be a cause for NPL. Attempt has been made in this study to identify the effect of bank size on the occurrence of NPL in Ethiopian context. Thus, the finding as per the majority of the respondents reveals that the level of assets of a bank does not affect loan performance. And also, the growth in banks asset will not affect the quality of loan.

Table 8: Statement relating to banks size (asset) and occurrence of NPL

\begin{tabular}{|l|l|l|l|l|l|l|l|l|}
\hline S.no & \multicolumn{1}{|c|}{ Statement } & $\begin{array}{c}\text { SA } \\
\%\end{array}$ & $\begin{array}{l}\mathrm{A} \\
\%\end{array}$ & $\begin{array}{c}\mathrm{N} \\
\%\end{array}$ & $\begin{array}{l}\text { DA } \\
\%\end{array}$ & $\begin{array}{l}\text { SDA } \\
\%\end{array}$ & Mean & $\begin{array}{l}\text { Standard } \\
\text { Deviation }\end{array}$ \\
\hline 1 & $\begin{array}{l}\text { The level of asset of a bank affects } \\
\text { loan performance }\end{array}$ & 3.7 & 24.7 & 35.8 & 32.1 & 3.7 & 3.074 & 0.932 \\
\hline 2 & $\begin{array}{l}\text { When banks asset level grows, NPL } \\
\text { also grows. }\end{array}$ & 1.2 & 11.1 & 39.5 & 40.7 & 7.4 & 3.419 & 0.834 \\
\hline
\end{tabular}

Source: Survey Outcome and own computation 


\section{Ownership type}

Banks can be established having different ownership structure the common ones being either private form of ownership or governmental ownership. Some studies revealed that the ownership structure of banks will have its own impact on the level of NPL occurrence. In this regard in some empirical literatures state banks are reported to have more incentives to take part in projects which are risky since they are more prone to $<<$ too big to fail problem $>$. Irrespective of such literatures, the finding of this study as shown in the following table indicates that the majority of respondents $(63 \%)$ believe that loan default is not related with banks ownership. However there is a study which is made by Walter and Werlang (1995), and which founds banks with higher government ownership recorded lower non-performing loans compared to private banks.

Table 9:Statements relating to Banks ownership type and occurrence of NPL

\begin{tabular}{|l|l|c|c|c|c|c|c|c|}
\hline S.no & Statement & SA & A & N & DA & SDA & Mean & $\begin{array}{l}\text { Standard } \\
\text { Deviation }\end{array}$ \\
\hline 1 & $\begin{array}{l}\text { There is no relationship between } \\
\text { Loan default and ownership type of } \\
\text { a bank (i.e., private or government) }\end{array}$ & 19.8 & 43.2 & 17.3 & 14.8 & 4.9 & 2.419 & 1.116 \\
\hline
\end{tabular}

Source: Survey Outcome and own computation

\subsubsection{Industry determinants of NPL}

The industry in which banks operate will have its own impact on loans quality the banks will provide. There are different industry related factors which are common for the cause of NPL. Among these factors the most common are the level of information sharing among banks and the existing foreclosure laws on collateralized properties. In this regard, majority of the respondents of this study (72.8\%) (Mean 2.197 and standard deviation 0.98) mentioned that the level of information sharing among banks has a direct effect on NPL. Additionally large volume of respondents $(58 \%)$ said that the existing foreclosure laws of banks decreases the level of NPL.

Table 10: Industry specific determinants and occurrence of NPL

\begin{tabular}{|l|l|l|l|l|l|l|l|l|}
\hline S.no & \multicolumn{1}{|c|}{ Statement } & $\begin{array}{c}\text { SA } \\
\%\end{array}$ & $\begin{array}{l}\mathrm{A} \\
\%\end{array}$ & $\begin{array}{l}\mathrm{N} \\
\%\end{array}$ & $\begin{array}{l}\text { DA } \\
\%\end{array}$ & $\begin{array}{l}\text { SDA } \\
\%\end{array}$ & $\begin{array}{l}\text { Mean } \\
\text { Standard } \\
\text { Deviation }\end{array}$ \\
\hline 1 & $\begin{array}{l}\text { Level of information sharing among } \\
\text { banks has a direct effect on NPL }\end{array}$ & 22.2 & 50.6 & 14.8 & 9.9 & 2.5 & 2.197 & 0.98 \\
\hline 2 & $\begin{array}{l}\text { The existing foreclosure laws (i.e., } \\
\text { possession on collateralized } \\
\text { property decreases the level of }\end{array}$ & 7.4 & 50.6 & 25.9 & 12.3 & 3.7 & 2.543 & 0.936 \\
\hline
\end{tabular}

Source: Survey Outcome and own computation 


\subsubsection{Macro-economic determinants of NPL}

The macroeconomic environment has a significant influence on the quality of loan portfolio in the banking sector. This study by considering four macro-economic factors namely; GDP, inflation rate, unemployment rate and foreign exchange rate has tried to forward questions for respondents to identify the magnitude of their effect for the occurrence of NPL. Accordingly, the response from the respondents has been generated as shown in the following table 11 .

Table 11: Macroeconomic determinants and occurrence of NPL

\begin{tabular}{|l|l|l|l|l|l|l|l|l|}
\hline S.no & \multicolumn{1}{|c|}{ Statement } & $\begin{array}{c}\text { SA } \\
\%\end{array}$ & $\begin{array}{l}\text { A } \\
\%\end{array}$ & $\begin{array}{l}\text { N } \\
\%\end{array}$ & $\begin{array}{l}\text { DA } \\
\%\end{array}$ & $\begin{array}{l}\text { SDA } \\
\%\end{array}$ & Mean & $\begin{array}{l}\text { Standard } \\
\text { Deviation }\end{array}$ \\
\hline 1 & $\begin{array}{l}\text { A rise in GDP is associated with a } \\
\text { fall in NPL ratio }\end{array}$ & 12.3 & 37 & 38.3 & 11.1 & 1.2 & 2.518 & 0.895 \\
\hline 2 & $\begin{array}{l}\text { A rise in inflation rate decreases a } \\
\text { loan quality }\end{array}$ & 8.6 & 55.6 & 27.2 & 7.4 & 1.2 & 2.37 & 0.797 \\
\hline 3 & $\begin{array}{l}\text { Unemployment growth leads to a } \\
\text { rise on NPL }\end{array}$ & 4.9 & 40.7 & 42 & 12.3 & 0 & 2.617 & 0.767 \\
\hline 4 & $\begin{array}{l}\text { Foreign exchange rate is directly } \\
\text { related to loan performance }\end{array}$ & 13.6 & 53.1 & 27.2 & 6.2 & 0 & 2.259 & 0.771 \\
\hline
\end{tabular}

Source: Survey Outcome and own computation

Their response as presented in table 11 indicates that all these factors have their own impact on loan performance. If we see these factors separately one by one we can observe based on the respondents response that an increase in GDP can minimize the occurrence of NPL to some extent. So this means banks which operate in countries which experience an increase in GDP will have lower NPL ratio. As it has been agreed by majority of respondents of the study, loans will have lower quality in situations where there is an increase in inflation. The bankers also have said that in countries where there is a continuous growth in unemployment there is an increase in NPLs. Finally in a similar fashion foreign exchange rate has been observed as having an impact on the quality of loan. In the following table majority of the respondents (i.e.,66.7\%) have revealed that the performance of a loan will directly be influenced by foreign exchange rate.

\section{CONCLUSION}

The finding of the study has revealed that the major loans which are non-performing from the sampled commercial banks is resulting from the loans provided for purposes of agriculture and domestic trade and services while the least portion of nonperforming loans is covered by export and import loans. It has also been evidenced in the study that different factors are contributing for the occurrence of credit risks in commercial banks of Ethiopia, the contributing factors being; bank specific factors, industry specific factors and macro-economic factors. These factors having different magnitude are triggering the occurrence of non-performing loans in such banks. 
Though different bank specific factors are contributing for the occurrence of NPLs, it has been observed from the response generated that NPLs is increasing mainly as a result of poorly negotiated credit terms, compromised integrity in lending, poor credit risk assessment and lack of skilled man power in credit assessment and analysis.

With respect to industry specific and macro-economic factors, level of information sharing among banks has gained a weight in the response of the bankers as having a direct effect on NPLs from industry specific variables while from macro-economic variables a rise in inflation rate and foreign exchange rate are observed as having major direct impact on loan performance.

\section{Acknowledgements}

We are pleased to extend our gratefulness for the help we receive in order to complete this research. First of all we would like to express our deepest gratitude to Jimma University for allowing us to undertake such a study by facilitating all the important supports including financial support so that we can undertake the study smoothly. On the other hand the cooperation that we get from all of the commercial banks along with their staffs was very interesting and so that we are very thankful for their assistance. Finally we thank Dr. Mathewos Kebede for his interesting cooperation while undertaking this study.

\section{REFERENCES}

Baboucek, Ivan and M. Jancar, (2005). "Effects of Macroeconomic Shock to the Quality of the Aggregate Loan Portfolio", Czech National Bank, Working Paper Series, No.1, 1-62.

Basel committee on Banking Supervision, (2000). Principles for the Management of Credit Risk.

Boudriga, A., Taktak, N., \&Jelloulo, S. (2009). Banking supervision and non-performing loans: a cross country analysis. Journal of Financial Economic Policy, 286-318.

Das, A. and Ghosh, S. (2007). Determinants of Credit Risk in Indian State-owned Banks: An Empirical Investigation. Economic Issues-Stoke on Trent, 12(2), 27-46.

Dash, M. and Kabra, G. (2010). The Determinants of Non-Performing Assets In Indian Commercial Bank: An Econometric Study. Middle Eastern Finance and Economics, 7, 94-106.

Fernandez, J., Martinez, J. \&Saurina, J., (2000). Credit Growth, Problem Loans and Credit Risk Provisioning in Spain. Bank of Spain, Working Paper, No. 0018.

Fofack, H. (2005). Non-performing loans in subSaharan Africa: Casual Analysis and Macroeconomic Implications. World Bank policy Research Working Paper No. 3769.

Hu, Jin-Li, Yang Li \& Yung-Ho, Chiu. (2006). Ownership and Non-performing Loans: Evidence from Taiwan's Banks. Developing Economies.

Jimenez, G. \& Jesus S.(2005). Credit cycles, credit risk, and prudential regulation. Banco de Espana.

National Bank of Ethiopia (2009), "Banking industry risk management survey report", National Bank of Ethiopia, Bank Supervision Directorate, Addis Ababa, Ethiopia.

Rajan, R \&Sarat C.(2003). Non-performing Loans and Terms of Credit of Public Sector Banks in India: An Empirical Assessment. Occasional Papers 24(3), 81-121, Reserve Bank of India.

Samad, A. (2012). Credit Risk Determinants of Bank Failure: Evidence from US Bank Failure, International Business Research, 5(9), 10-15. 
Thiagrajan, S.Ayyappan, S. and Ramachandran, A. (2011), Credit risk determinants of public and private sector banks in India, European Journal of Economics, Finance and Administrative Science, 34, 147-154.

Vogiazas, S., \&Nikolaidou, E. (2011). Investigating the Determinants of Nonperforming Loans in the Romanian Banking System: An Empirical Study with Reference to the Greek Crisis. Economics Research International.
Walter, N. and Werlang, S. (1995). Inflationary Bias and State owned Financial Institutions. Journal of Development Economics, 47, 135-54.

Waweru, N.M. \&Kalani, V.M. (2009). Commercial banking crisis in Kenya: causes and remedies. Africa Journal of Accounting, Economic Economics, Finance and banking research, 4(4), 12-32. 